\title{
PENERAPAN HYPNOTEACHING UNTUK MENINGKATKAN KEMAMPUAN SELF-REGULATED LEARNING MAHASISWA PAPUA DALAM MATA KULIAH DESAIN PEMBELAJARAN
}

\author{
Ega Edistria1), Bobbi Rahman²), Abdul Azis Abdillah ${ }^{3)}$ \\ ${ }^{1,2}$ STKIP Surya ${ }^{3}$ Politeknik Negeri Jakarta \\ e-mail : ${ }^{1}$ ega.edistria@stkipsurya.ac.id, ${ }^{2}$ bobbi.rahman@stkipsurya.ac.id, ${ }^{3}$ abdul.azis.a@stkipsurya.ac.id
}

\begin{abstract}
The low ability of Self-Regulated Learning students who mostly come from the remote area in Papua, motivates researchers to conduct research by applying Hypnoteaching in the learning process. One of the reasons for the low ability of Self-Regulated Learning students is the habit of those who have not been able to regulate and direct themselves in learning. Hypnoteaching, also called giving positive suggestions, is expected to be able to direct their minds to change learning behavior to be organized and directed. In other words, this will affect the ability of student Self-Regulated Learning. The purpose of this study was to find out: 1) how to increase the ability of Papuan Self-Regulated Learning after Hypnoteaching was applied in Mathematics Courses, 2) how students respond to the application of Hypnoteaching in Mathematics Courses. This type of research is Classroom Action Research with the subject of research are Papuan students in the Mathematics Learning Design Course at STKIP Surya Tangerang 2017/2018 Academic Year. Data collection techniques in the form of questionnaires, field notes, and observation sheets. The data analyzed is only questionnaire data by processing questionnaire scores that are converted into interval data, then determined attitude scores and neutral scores. The results showed that the application of hypnoteaching can improve the ability of self-regulated learning for Papuan students to be better. This can be seen from the percentage of attitude scores related to the ability of self-regulated learning which experienced an increase of initially by $61 \%$ in the pre-cycle, increasing to $72 \%$ in the first cycle and $74 \%$ in the second cycle. Regarding student responses, it was concluded that students gave a positive response to the application of hypnoteaching.
\end{abstract}

Key words: Self-Regulated Learning, Hypnoteaching, Classroom Action Research

\begin{abstract}
Abstrak
Rendahnya kemampuan Self-Regulated Learning mahasiswa yang mayoritas berasal dari daerah Pedalaman Papua, melatarbelakangi peneliti untuk melakukan penelitian dengan menerapkan Hypnoteaching dalam proses pembelajaran. Salah satu penyebab rendahnya rendahnya kemampuan Self-Regulated Learning mahasiswa adalah kebiasaan mereka yang belum bisa mengatur dan mengarahkan diri sendiri dalam belajar. Hypnoteaching yang disebut juga pemberian sugesti positif diharapkan mampu mengarahkan pikiran mereka untuk merubah perilaku belajar menjadi teratur dan terarah. Dengan kata lain hal tersebut, akan berpengaruh terhadap kemampuan Self-Regulated Learning mahasiswa. Tujuan penelitian ini adalah untuk mengetahui: 1) bagaimanakah peningkatan kemampuan SelfRegulated Learning Mahasiswa Papua setelah diterapkan Hypnoteaching dalam Mata Kuliah Desain Pembelajaran Matematika, 2) bagaimanakah respon mahasiswa terhadap penerapan Hypnoteaching dalam Mata Kuliah Desain Pembelajaran Matematika. Jenis penelitian merupakan Penelitian Tindakan Kelas dengan subjek penelitian adalah mahasiswa Papua pada Mata Kuliah Desain Pembelajaran Matematika di STKIP Surya
\end{abstract}


Tangerang Tahun Pelajaran 2017/2018. Teknik pengumpulan data berupa angket, catatan lapangan, dan lembar observasi. Data yang dianalis hanya data angket dengan cara mengolah skor angket yang dikonversi menjadi data interval, kemudian ditentukan skor sikap dan skor netralnya. Hasil penelitian menunjukan bahwa penerapan hypnoteaching dapat meningkatkan kemampuan self-regulated learning mahasiswa Papua menjadi lebih baik. Hal ini dapat dilihat dari persentase skor sikap terkait kemampuan self-regulated learning yang mengalami peningkatan dari awalnya sebesar $61 \%$ pada pra siklus, meningkat menjadi 72\% pada siklus I dan 74 \% pada siklus II. Terkait respon mahasiswa diperoleh kesimpulan bahwa mahasiswa memberikan respon positif terhadap penerapan hypnoteaching yang dilakukan.

Kata kunci: Self-Regulated Learning, Hypnoteaching, Penelitian Tindakan Kelas

\section{PENDAHULUAN}

Salah satu karakteristik pembelajaran di perguruan tinggi adalah berpusat pada mahasiswa, sebagimana yang tercantum dalam Permenristek No. 44 tahun 2015 pasal 11 ayat 1 . Selain itu juga dalam pasal yang sama di ayat 10 juga dinyatakan bahwa berpusat pada mahasiswa yang dimaksudkan adalah proses pembelajaran di perguruan tinggi mengutamakan pengembangan kemandirian mahasiswa dalam mencari dan menemukan pengetahuan. Kemandirian tersebut merupakan kemampuan mahasiswa dalam mengatur kegiatan belajar, mengontrol prilaku belajar, serta mengetahui kebutuhan belajarnya sendiri atau disebut juga SelfRegulated Learning (SRL).

SRL merupakan perancangan dan pemantauan diri secara seksama terhadap proses kognitif dan afektif dalam menyelesaikan suatuyang berkaitan dengan tugas akademik. Menurut Hendriana, H., \& Soemarmo U (2014) ada 3 karakteristik yang terkandung dalam pengertian SRL, yaitu: (1) Individu merancang belajarnya sendiri sesuai dengan keperluan atau tujuan individu yang bersangkutan, (2) Individu memilih strategi sendiri dan melaksanakan rancangan belajarnya, dan kemudian (3) Individu memantau kemajuan belajarnya sendiri, mengevaluasi dan dibandingkan dengan standar tertentu. SRL lebih merupakan proses pengarahan diri dalam mentransformasikan kemampuan mental mereka ke dalam keterampilan akademis (Zimmerman, 2002).

Setiap mahasiswa diharapkan memiliki kemampuan SRL agar mereka mampu mengatur, merancang dan memotivasi diri untuk selalu mengarahkan diri ke arah perilaku positif dan aktivitas belajar yang penuh tanggung jawab. Namun hal tersebut, belum begitu terlihat di Sekolah Tinggi Keguruan dan Ilmu Pendidikan Surya yang mayoritas mahasiswanya berasal dari daerah pedalaman Papua. Sebagai salah satu pengajar, khususnya mengajarkan mata kuliah Desain Pembelajaran Matematika selama 3 tahun berturut-turut, peneliti melihat sebagian besar mahasiswa belum mampu mengatur dan mengarahkan diri mereka sendiri agar bisa mengikuti perkuliahan dengan baik. Mereka seperti mengalami kesulitan untuk mengerjakan tugas yang diberikan dengan benar. Hal itu terlihat pada saat mempresentasikan apa yang mereka buat, dan apa yang disajikan cenderung tidak sesuai dengan apa yang diminta oleh dosen.

Menurut peneliti ada banyak faktor yang menyebabkan hal seperti itu terjadi, salah satunya adalah kebiasaan mereka yang belum bisa mengatur dan mengarahkan diri sendiri dalam banyak hal khususnya belajar. Berdasarkan hasil wawancara peneliti dengan beberapa mahasiswa diketahui bahwa selama 
belajar dari SD, SMP, dan SMA, mereka kurang mendapatkan pengalaman belajar yang semestinya dan mereka juga jarang diberikan tugas oleh guru. Hal lainnya ketika musim panen atau berburu tiba sekolah lebih sering diliburkan karena guru lebih memilih untuk pergi ke ladang maupun ke hutan dari pada mengajar. Sekolah bukan suatu hal yang penting bagi sebagian besar masyarakat di sana. Tidak mengherankan jika kondisi tersebut berpengaruh terhadap pola pikir, sikap dan kebiasaan mereka dalam belajar, seperti sulit dalam memahami tugas, tidak disiplin dalam mengerjakan tugas, kurang motivasi dan tidak bisa mengatur atau mendisiplinkan dirinya dalam menjalankan perkuliahan, dengan kata lain dapat dikatakan Self-Regulated Learning (SRL) mahasiswa cenderung rendah.

Oleh karena itu, perlu suatu upaya untuk mengembangkan Self-Regulated Learning (SRL) mahasiswa. Salah satunya dengan menerapkan Hypnoteaching dalam kegiatan pembelajaran di kelas. Hypoteaching berasal dari dua kata yaitu hypnosis dan teaching Hypnosis dapat diartikan sebagai sugesti, sedangkan teaching adalah kegiatan pembelajaran. Menurut Edistria (2012) Hypoteaching merupakan penyampaian proses pembelajaran dengan cara memberikan sugesti menggunakan kata-kata persuasif untuk mengondisikan peserta didik agar berada dalam kondisi fokus. Pemberian sugesti dilakukan untuk "mengaktifkan" pikiran bawah sadar mereka, karena pikiran bawah sadar (sub-conscisius mind) memiliki pengaruh lebih besar terhadap perilaku, pola pikir, sikap, dan kebiasaan dari pada pikiran sadar (conscisius mind) tiap individu (Yustisia, 2012). Sugesti yang diberikan juga bisa menjadi suatu alat yang kuat dan sangat membantu seseorang membuat perubahan positif dalam hidup mereka (Banyan, 2005). Kondisi seperti itu diharapkan mampu membatu dosen untuk dapat mengarahkan pikiran, perasaan, dan tingkah laku mahasiswa ke arah positif seperti mengatur kegiatan belajar, mengontrol prilaku belajar, serta mengetahui kebutuhan belajarnya sendiri. Dalam penelitian ini penerapan hypnoteaching melalui beberapa langkah yaitu; (1) niatkan dan memotivasi dalam diri sendiri; (2) melakukan pacing; (3) melakukan leading; (4) menggunakan kata positif, (5) memberikan pujian; dan (6) melakukan modelling. (Hajar, 2011)

Jadi menerapkan hypnoteaching dalam pembelajaran, mengkondisikan mahasiswa berada dalam keadaan sadar seutuhnya dengan mata terbuka, mereka dibuat rileks pikirannya sehingga bisa fokus pada yang disampaikan pengajar sehingga berdampak kepada sikap dan motivasi belajar mereka. Seperti yang dikatakan oleh Isworo, et al. (2013) dalam jurnal penelitiannya yaitu hypnoteaching salah satunya dapat meningkatkan motivasi peserta didik. Kondisi seperti itu diharapkan mampu membatu pengajar untuk dapat mengarahkan pikiran, perasaan, dan tingkah laku mahasiswa ke arah positif seperti mengatur kegiatan belajar, mengontrol prilaku belajar, serta mengetahui kebutuhan belajarnya sendiri. Secara tidak langsung dapat dikatakan, dengan adanya penerapan hypnoteaching maka akan berpengaruh terhadap perkembangan kemampuan SelfRegulated Learning (SRL) mahasiswa. Hal inilah yang menjadi alasan peneliti untuk melakukan penelitian ini dengan judul Penerapan Hypnoteaching untuk Meningkatkan Kemampuan SelfRegulated Learning Mahasiswa Papua dalam Mata Kuliah Desain Pembelajaran Matematika.

\section{Rumusan Masalah}

Berdasarkan latar belakang yang telah diuraikan di atas, maka rumusan masalah dari penelitian ini adalah bagaimanakah peningkatan kemampuan Self-Regulated Learning Mahasiswa Papua setelah diterapkan Hypnoteaching dalam Mata Kuliah Desain Pembelajaran Matematika. 
Berdasarkan rumusan masalah tersebut, maka tujuan penelitian ini adalah untuk mengetahui bagaimanakah peningkatan kemampuan Self-Regulated Learning Mahasiswa Papua setelah diterapkan Hypnoteaching dalam Mata Kuliah Desain Pembelajaran Matematika.

\section{METODOLOGI PENELITIAN}

Penelitian ini merupakan penelitian tindakan kelas. Pemilihan jenis penelitian ini bertujuan peningkatan kualitas pembelajaran dalam perkuliahan. Jenis tindakan yang dilakukan adalah penerapan Hypnoteaching untuk meningkatkan kemampuan SelfRegulated Learning mahasiswa Papua pada Mata Kuliah Desain pembelajaran. Model PTK yang digunakan adalah model Kemmis-McTaggar yang dilakukan melalui empat langkah. Langkah tersebut dapat digambarkan dalam skema berikut:

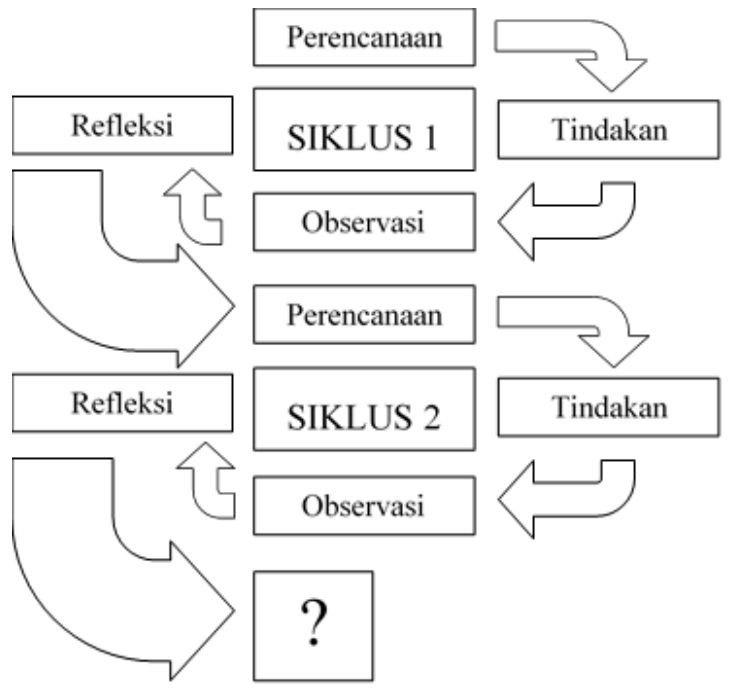

Gambar 1. Bagan Siklus Penelitian Tindakan Kelas

Berikut penjelasan tahap-tahap dalam penelitian ini:

1. Perencanaan

Penelitian direncanakan sebanyak 2 siklus. Selain merencanakan banyak siklus, pada tahapan ini peneliti juga mengumpulkan informasi, pengetahuan, dan literatur yang terkait dengan penelitian. Selanjutnya peneliti merancang instrumen dan mendesain penelitian. Instrumen yang digunakan berupa angket untuk mengetahui Self-Regulated Learning

2. Tindakan

Dalam 1 siklus penelitian, tindakan dilakukan dalam 3 kali pertemuan perkuliahan. Sebelum melakukan tindakan dalam pembelajaran, terlebih dahulu peneliti meminta siswa untuk mengisi angket Self-Regulated Learning. Selanjutnya akan dalam pembelajaran, peneliti akan menerapkan Hypnoteaching dengan langkah-langkah sebagai berikut:

a. Sebelum memulai pembelajaran, selain berdoa peneliti menanamkan niat dan memotivasi diri sendiri terlebih dahulu agar berkomitmen memberikan yang terbaik untuk mahasiswa.

b. Peneliti membuka pertemuan dengan melakukan Pacing yaitu memberikan sugestisugesti positif dan bahasa yang lembut agar mahasiswa nyaman dan tidak merasa terbebani dengan perkuliahan yang dilakukan. Selain itu Pacing yang dilakukan, bisa menimbulkan kesadaran untuk belajar dalam diri mahasiswa.

c. Selanjutnya peneliti membagi mahasiswa menjadi beberapa kelompok. Setiap kelompok mendapatkan tugas yang sama berupa mempersiapkan materi yang akan dibahas. Dalam belajar kelompok mereka diminta untuk mampu bertanggung jawab terhadap tugas masing-masing indivisu. Satu kelompok yang terpilih, akan ditugaskan untuk mempersentasikan hasil diskusinya di depan kelas. 
Pada saat memberikan pengarahan kepada kelompok, peneliti melakukan Leading untuk mengarahkan mahasiswa agar mereka termotivasi melakukan yang terbaik dan bertanggung jawab terhadap kelompoknya masing-masing.

d. Di akhir pembelajaran, peneliti memberikan tugas kepada mahasiswa untuk membuat laporan tentang materi kuliah yang dipelajari secara individu. Selajutnya peneliti akan memberikan pujian dan penghargaan kepada mahasiswa yang bersikap baik selama pembelajaran. Pujian yang diberikan bisa membuat perubahan positif dalam diri mahasiswa tersebut, dan memotivasi mahasiswa lain untuk melakukan hal yang lebih baik lagi.

e. Diakhir setiap siklus dosen meminta mahasiswa mengisi angket Self-Regulated Learning dan angket respon mahasiswa terhadap penerapan Hypnoteaching.

3. Observasi

Tahapan observasi dilakukan bersamaan pada tahapan pelaksanaan, karena observasi dijalankan saat pelaksanaan pembelajaran berlangsung. Selama pembelajaran peneliti menuliskan catatan lapangan/ catatan pengamatan untuk mencatat halhal yang dirasa penting selama penelitian serta meminta rekan sesama dosen untuk mengisi lembar observasi yang telah disediakan untuk mengamati penerapan Hypnoteaching selama pembelajaran.

4. Refleksi

Refleksi dilakukan berdasarkan pengkajian terhadap data skor angket Self-Regulated Learning untuk melihat dampak tindakan pada suatu siklus. Selain itu juga dilakukan kajian terhadap respon mahasiswa terkait proses pembelajaran yang telah dilakukan. Selanjutnya berdasarkan hasil kajian tindakan dan proses pembelajaran tersebut maka peneliti bersama tim peneliti akan mendiskusikan apakah pembelajaran yang dilakukan telah sesuai dengan yang direncanakan. Jika saat refleksi masih ditemukan hal-hal yang belum tercapai seperti yang diharapkan, maka bisa dilakukan perbaikan pada pelaksanaan siklus berikutnya.

Penelitian ini dilaksanakan di STKIP Surya dengan subjek penelitiannya adalah mahasiswa Papua pada Mata Kuliah Desain Pembelajaran Matematika Tahun Pelajaran 2017/2018. Pengumpulan data dilakukan dengan mengembangkan instrumen utama berupa angket. yang mengukur Self-Regulated Learning (SRL) yang terdiri dari 4 indikator seperti kesadaran akan tujuan belajar, kesadaran akan tanggung jawab belajar, kontinuitas belajar, dan efisiensi belajar. Berdasarkan hasil angket tersebut, langkah pertama yang dilakukan adalah memberikan skor pada setiap butir pernyataan siswa dengan berpedoman pada skala sikap model Likert. Skor tersebut kemudian dikonversi menjadi data interval, kemudian ditentukan skor sikap dan skor netralnya. Peningkatan self-regulated learning mahasiswa dilihat dari kenaikan persentase skor sikap dari pengolahan data angket.

\section{HASIL DAN PEMBAHASAN}

Penelitian dilakukan dengan menerapkan hypnoteaching di kelas perkuliahan desain pembelajaran matematika pada semester ganjil tahun akademik 2017/2018 Sekolah Tinggi Keguruan dan Ilmu Pendidikan (STKIP) 
Surya. Dimulai tanggal 22 Agustus dan selesai pada 3 Oktober 2017 dengan total pertemuan sebanyak 6 kali. Mahasiswa pada kelas tersebut berjumlah 16 orang yang terdiri dari 5 perempuan dan 11 lakilaki yang berasal dari darah $3 \mathrm{~T}$ (Terluar, Terdepan dan Tertinggal) seperti dari Papua yaitu daerah Pengunungan Arfak , Kepulauan Yapen, dan Puncak Jaya.

Karakteristik mahasiswa yang menjadi subjek penelitian bersifat homogen yaitu mahasiswa yang memiliki kemampuan akademik yang relatif rendah dengan IPK di bawah rata-rata. Selain kemampuan yang rendah, berdasarkan pengalaman peneliti yang beberapa kali mengajar mereka di mata kuliah lainnya, peneliti mengetahui bahwa sebagian besar mahasiswa juga cenderung bolos perkuliahan, suka telat masuk kelas, jarang mengulang materi perkuliahan, kurang aktif selama pembelajaran dan suka telat menyerahkan tugas atau dapat dikatakan mahasiswa-mahasiswa tersebut memiliki self-regulated learning yang masih rendah.

Penerapan Hypnoteaching yang dimaksud tidak seperti hipnosis yang biasa dilakukan yaitu membuat pesertanya tertidur, melainkan lebih ke cara penyampaian dalam proses pembelajaran dengan memberikan sugesti menggunakan kata-kata persuasif untuk mengondisikan mahasiswa agar selalu berada dalam kondisi fokus. Secara umum Hypnoteaching memiliki 6 langkah yaitu niat dan motivasi pacing; leading, menggunakan kata positif, memberikan pujian, dan modeling sebagai sintaks dalam pembelajaran.

Pada pra tindakan terlebih dahulu sudah dilakukan dulu pengambilan data awal terkait kemampuan self-regulated learning mahasiswa berupa skor angket. Berdasarkan perhitungan data skor angket tersebut diperoleh persentase skor sikap siswa sebesar 61\%, jika dibandingkan dengan skor netral yaitu $60 \%$, secara teori kemampuan mahasiswa sudah menunjukan nilai yang positif, tapi kemampuan self-regulated learning masih perlu ditingkatkan lagi karena karena jarak dari skor netral dengan skor sikap siswa masih kecil. Jika dilihat dari skor perindikator, masih ada indikator yang memiliki skor dibawah skor netral yaitu indikator kesadaran akan tanggung jawab belajar dan indikator kontinuitas belajar masing-masing memiliki skor 59\% dan $60 \%$.

Deskripsi Data Penelitian Siklus I (22 Agustus - 5 September 2017)

Sebelum dilaksanakannya siklus I terlebih dahulu peneliti menentukan materi pembelajaran berdasarkan Kompetensi Dasar yang telah ditetapkan. Selanjutnya membuat perencanaan pembelajaran dalam bentuk RPP, serta menentukan instrument yang akan digunakan untuk mengambil data penelitian.

Sesuai dengan rancangan pembelajaran yang dibuat, dosen menerapkan hypnoteaching dalam perkuliahan desain pembelajaran matematika. Sebelum memulai pembelajaran, peneliti mengajak mahasiswa untuk terlebih dahulu berdoa selain itu peneliti menanamkan niat dan memotivasi diri sendiri terlebih dahulu agar berkomitmen untuk memberikan yang terbaik untuk mahasiswa. Setelah berdoa peneliti melakukan Pacing yaitu memberikan sugesti-sugesti positif dan bahasa yang lembut agar mahasiswa nyaman dan tidak merasa terbebani dengan perkuliahan yang dilakukan. Selain itu Pacing yang dilakukan, bisa menimbulkan kesadaran untuk belajar dalam diri mahasiswa. Selanjutnya peneliti meminta mahasiswa berdiri dan melakukan gerakan relaksasi sederhana untuk mengatur pernafasan. Hal itu dilakukan agar mahasiswa bisa lebih santai serta menikmati pengalaman belajar yang akan dilakukan.

Pada kegiatan inti, mahasiswa diminta untuk melakukan diskusi kelompok. Setiap kelompok mendapatkan tugas yang sama berupa mempersiapkan materi yang akan dibahas secara bersama-sama di 
akhir sesi pembelajaran. Pada saat mahasiswa melakukan diskusi kelompok peneliti melakukan Leading sebagai salah satu bagian dari hypnoteaching yang bertujuan untuk mengarahkan mahasiswa agar termotivasi melakukan yang terbaik dan bertanggung jawab terhadap kelompoknya masing-masing.

Leading yang dilakukan oleh dosen berupa pemberian kata-kata positif untuk memberikan semangat kepada mahasiswa yang sedang bekerja, ataupun membuat mahasiswa yang kurang fokus agar menjadi fokus dalam mengerjakan tugas kelompoknya. Setelah diskusi kelompok selesai dilaksanakan, maka peneliti meminta salah satu kelompok untuk mempersentasikan hasil diskusinya di depan kelas sedangkan kelompok yang lainya mengomentari apa yang disampaikan kelompok penyaji.

Pada sesi presentasi, kelompok yang tidak tampil menangapi kelompok yang tampil. Di akhir pembelajaran, dosen memberikan kesimpulan terkait materi yang telah dibahas serta memberikan tugas untuk minggu depan. Penutup dari proses pembelajaran diakhiri dengan memberikan pujian kepada kelompok dan mahasiswa yang sudah aktif serta mengikuti pembelajaran dengan baik. Penghargaan diberikan pada akhir siklus I berupa bungkusan yang isinya alat tulis yang bisa diginakan untuk keperluan kuliah mereka. Berikut foto-foto saat dosen memberikan reward kepada mahasiswa yang mendapatkan apresiasi atas hal-hal baik yang mereka lakukan selama proses pembelajaran selama 3 kali pertemuan.

Hal lain yang juga dilakukan dalam penerapan hypnoteaching adalah modeling yaitu memberi tauladan melalui ucapan dan perilaku yang konsisten. Peneliti mencontohkan bagaimana cara berkomunikasi yang baik, bertutur kata yang baik serta bersikap yang santun. Berkomunikasi yang baik dapat dilatih mulai dari saat diskusi kelompok yang mereka lakukan, ataupun ketika bertanya kepada dosen saat ada sesuatu yang tidak dipahami. Hal tersebut diharapkan dapat menjadi acuan bagi mereka sebagai calon seorang guru yang akan membimbing siswa-siswa mereka saat kembali mengabdi ke daerah asal mereka.

\section{Hasil Observasi Pada Siklus I}

Siklus 1 dilakukan sebanyak 3 kali pertemuan setiap hari Selasa pada tanggal 22 ,29 Agustus dan 5 September 2017. Setiap pertemuan dimulai pukul 13.00 WIB - 15.30 WIB. Hal pertama yang peneliti amati adalah kedisiplinan mahasiswa yang datang perkuliahan dengan tepat waktu. Pada pertemuan pertama hanya 10 mahasiswa yang hadir tepat waktu. Akan tetapi pada pertemuan kedua dan ketiga mengalami peningkatan. Hal tersebut peneliti amati karena menghadiri perkuliahan dengan tepat waktu merupakan salah satu aspek dari indikator self-regulated learning yaitu efisiensi belajar. Untuk data lebih jelas dapat dilihat pada Tabel 1 .

Selama-lebih kurang 15 menit di awal perkuliahan peneliti memberikan katakata positif, untuk membuat mereka termotivasi dan bersemangat dalam perkuliahan. Selain itu kata-kata positif yang diberikan bertujuan untuk membuat mereka bisa menikmati setiap proses pembelajaran yang dilakukan.

Selain itu peneliti bersama-sama mahasiswa melakukan relaksasi dengan meminta mahasiswa untuk sama-sama berdiri lalu menutup mata sembari menghirup dan melepaskan nafas secara perlahan. Hal tersebut dilakukan supaya mereka bisa siap untuk mengalami proses pembelajaran dan tidak memikirkan hal lain selain kegiatan belajar. Pada awalnya banyak mahasiswa yang masih malu-malu dan tertawa karena merasa lucu ketika melakukan kegiatan ini. Akan tetapi pada pertemuan selanjutnya mahasiswa sudah bisa menikamti dan merasakan efek dari relaksasi yang dilakukan. Salah satunya mahasiswa terlihat lebih segar dan santai, karena melihat jadwal perkuliahan adalah 
waktu-waktu dimana mahasiswa cenderung mengantuk sehabis makan siang. Kegiatan yang dilakukan tersebut merupakan bagian dari penerapan hypnoteaching yaitu pacing.

Sebelum memasuki kegiatan inti perkuliahan, peneliti terlebih dahulu menanyakan kepada mahasiswa apakah ada diantara mereka yang membaca atau mempersiapkan diri dengan membaca materi terlebih dahulu. Pada pertemuan pertama tidak ada satupun mahasiswa yang melakukan, hal tersebut mungkin diakibatkan karena pertemuan pertama dilakukan persis di awal perkuliahan dimulai. Sedangkan untuk pertemuan kedua dan ketiga, mahasiswa sudah mulai untuk mempersiapkan diri sebelum perkuliahan dilakukan. Data mengenai banyak mahasiswa yang mempersiapkan diri dengan membaca materi sebelum perkuliahan dimulai dapat dilihat pada tabel 2.

Aktifitas terkait membaca materi sebelum perkuliahan dimulai merupakan salah satu aspek dari indikator kemampuan self-regulated learning mahasiswa yaitu kesadaran akan tanggungjawab belajar. Pada kegiatan inti peneliti meminta mahasiswa untuk duduk secara berkelompok sesuai dengan yang telah peneliti tentukan. Pembagian kelompok dibuat heterogen berdasarkan kemampuan masing-masing mahasiswa. Terdapat 5 kelompok yang beranggotakan beranggotakan $3-4$ mahasiswa. Setelah mereka duduk dengan kelompoknya peneliti meminta mereka untuk mendiskuikan dan meringkas materi sesuai yang ditentukan. Pada pertemuan pertama, kedua dan ketiga secara berurutan materi yang dibahas adalah “Tugas, Peran, dan Kompetensi Guru, Desain Pembelajaran, dan Perangkat Pembelajaran”

Berdasarkan pengamatan, hampir secara keseluruhan mahasiswa terlihat focus dan tidak ada yang mengantuk selama proses pembelajaran. Pada saat berdiskusipun mahasiswa terlihat focus mengerjakan tugas yang diberikan bersama teman kelompoknya. Peneliti melihat mahasiswa berusaha untuk mengerjakan tugas yang diberikan. Tugas yang diberikan berupa membuat ringkasan terkait materi yang akan dipresentasikan diakhir pembelajaran. Diskusi kelompok dilakukan selama lebih kurang 90 menit.. Pada saat mahasiswa melakukan diskusi kelompok, peneliti berkeliling melihat diskusi yang dilakukan, sambil melakukan leading agar mahasiswa tetap focus dan menjaga semangat mereka. Ada beberapa mahasiswa yang terlihat bingung ataupun tidak focus dalam berdiskusi namun dengan leading yang dilakukan, peneliti memberikan semangat dan kata-kata positif bahwa mereka bisa mengerjakan tugas yang diberikan dengan baik.

Pada setiap pertemuan, peneliti juga langsung menilai hasil diskusi kelompok. Kelompok terbaik akan peneliti minta untuk mempresentasikan hasil diskusi mereka, sedangkan kelompok lainnya menanggapi presentasi dari kelompok yang tampil. Selama 3 kali pertemuan, peneliti merangkum data aktifitas kemampuan mahasiswa lainnya seperti tanggungjawab dalam menyerahkan tugas yang diberikan sesuai waktu yang ditentukan serta kesesuaian tugas yang dibuat dengan yang diperintahkan. Data tersebut peneliti peroleh berdasarkan hasil kelompok dan dari penilaian tugas-tugas individu yang mereka buat. Data tersebut dapat dilihat pada Tabel 3.

Berdasarkan Tabel 3 di atas terlihat ada peningkatan aktifitas belajar mahasiswa. aktifitas tersebut tercangkup ke dalam indikator Self-Regulated Leaning yaitu kesadaran akan tujuan belajar dan kontinuitas belajar.

Setelah selesai proses pembelajaran pada siklus I, peneliti memberikan penghargaan kepada mahasiswa. Ada dua jenis penghargaan yang diberikan, pertama kepada kelompok terbaik, dan yang kedua kepada mahasiswa terbaik. Berdasarkan catatan lapangan terdapat 
dua kelompok terbaik selama proses pembelajaran dilakukan. Hal tersebut dinilai saat kegiatan melakukan diskusi dan dari tugas kelompok dari diskusi yang dilakukan. Untuk maahasiswa yang terbaik ditentukan berdasarkan mahasiswa yang rajin, aktif dan mengerjakan tugas dengan baik dan sesuai dengan yang diminta.

\section{Hasil Analisis Skor Angket Self- Reguleted Learning Siklus I}

Setelah dilakukan perkuliahan selama 3 kali pertemuan, di akhir pertemuan ketiga peneliti meminta mahasiswa untuk mengisi angket self-regulated learning dan angket hypnoteaching. Berdasarkan perhitungan skor angket self-regulated learning diperoleh data pada tabel 4 .

Dari Tabel 4, perhitungan skor angket pada siklus I kemampuan SRL mahasiswa mengalami peningkatan yaitu dari 61,8\% menjadi $72,8 \%$. Untuk lebih jelas, peneliti juga mendeskripsikan skor angket SRL perindikator pada tabel 5 .

Jika dilihat perindikator, sebaran skor yang diperoleh dari siklus I menunjukan sikap positif, jika dibandingkan dari pra siklus,persentase keempat indikator tersebut mengalami kenaikan. Untuk lebih jelasnya sebaran data indikator pada pra siklus dan siklus I dapat dilihat pada gambar 2.

Grafik di atas menunjukan adanya kenaikan skor dari pra siklus. Jika dilihat dari kriteria penskoran, yang pada pra siklus masih ada dua indikator yang berada pada kategori sedang, maka pada siklus I semua indikator sudah berada dikategori tinggi.

\section{Deskripsi Data Penelitian Siklus II (19 September - 3 Oktober 2017)}

Tahap perencanan tindakan pada siklus II meliputi membuat dan memperbaiki RPP untuk pembelajaran di siklus II. Adapun materinya melanjutkan dari siklus I sedangkan untuk instrumentnya masih tetap menggunakan yang telah dibuat pada siklus I. RPP yang dibuat pada siklus II hampir sama dengan RPP pada siklus I, bedanya pada pembelajaran di siklus II tidak ada lagi diskusi dalam bentuk kelompok. Mereka langsung diminta belajar tanpa dikondisikan secara berkelompok. Selain itu di siklus II dosen menjelaskan materi perkuliahan yang pada siklus I tidak dilakukan.

Memasuki proses pembelajaran dosen masih melakukan relaksasi berupa gerakan sederhana untuk mengatur pernafasan. Setelah melakukan gerakan sederhana untuk relaksasi dan melakukan pernafasan, dosen langsung masuk ke kegiatan inti yaitu menjelaskan materi perkuliahan. Saat menjelaskan materi perkuliahan, dosen menerapkan salah satu langkah hypnoteaching yaitu pacing. Pacing yang dilakukan berupa menggunakan dan bahasa yang lembut dalam menyampaikan materi agar mahasiswa merasa nyaman dan tidak merasa terbebani dengan pembelajaran yang dilakukan. Setelah dosen selesai menjelaskan materi, mahasiswa diberikan tugas untuk dikerjakan secara individu. Pada saat mahasiswa mengerjakan tugas maka dosen berkeliling untuk melakukan leading agar mahasiswa bertanggungjawab terhadap tugas yang diberikan. Diakhir pembelajaran dosen memberikan kesimpulan terkait materi yang telah dipelari dan memberikan tugas kepada mahasiswa untuk dikerjakan di asrama. Diakhir siklus II dosen juga memberikan Pada siklus II dosen juga memberikan reward kepada mahasiswa yang mendapatkan apresiasi atas hal-hal baik yang mereka lakukan selama proses pembelajaran selama 3 kali pertemuan.

\section{Hasil Observasi Pada Siklus II}

Siklus II dilakukan langsung setelah siklus I. Banyak siklus II juga 3 kali pertemuan yang dilakukan setiap hari selasa mulai pada tanggal 19, 26 September dan 3 Oktober 2017. Lama waktu setiap pertemuan tetap sama yaitu 3 x 50 menit. Melanjutkan dari siklus I, pada siklus II peneliti tetap 
memperhatikan terkait kedisiplinan mahasiswa untuk datang pada perkuliahan secara tepat waktu. Pada pertemuan pertama siklus II ini, mahasiswa yang datang tepat waktu masih sama pada pertemuan ke 3 di siklus I yaitu sebanyak 14 mahasiswa. Akan tetapi di pertemuan ke 2 dan ke 3 siklus II, jumlah tersebut menjadi naik, walau belum bisa mencapai jumlah sempurna. Data tersebut dapat dilihat pada tabel 6 .

Pelaksanaan proses pembelajaran di siklus II secara umum tidak berbeda dengan siklus I yaitu langkah-langkah hypnoteaching masih dilakukan dalam proses pembelajaran, bedanya hanya pada tahapan inti yaitu tidak ada lagi sesi diskusi kelompok. Pembelajaran pada siklus II ini walau tetap berpusat pada mahasiswa, tetapi lebih ke sistem belajar secara individu. Sebelum pembelajaran dimulai terlebih dahulu dosen akan bertanya kepada mahasiswa, apakah mereka sudah membaca materi atau mempersiapkan diri terkait materi yang akan diajarkan. Berdasarkan catatan peneliti dan pengakuan mahasiswa, masih ada mahasiswa yang lupa untuk membaca materi sebelum perkuliahan dimulai. Hal tersebut berkaitan dengan indikator SRL mahasiswa yaitu kesadaran akan tanggungjawab belajar. Berikut data mengenai kesiapan mahasiswa untuk mengikuti perkuliahan.

Pada kegiatan inti dosen menjelaskan materi, dengan mererapkan pacing yaitu menjelaskan dan memberikan materi menggunakan bahasa yang lembut. Pacing dilakukan agar mahasiswa bisa mudah memahami dan tidak merasa terbebani dengan materi yang diberikan. Materi yang diberikan pada siklus II melanjutkan materi di siklus I, akan tetapi ada sedikit perubahan, yaitu yang awalnya direncanakan seperti Tabel 7, tetapi hanya sampai pada materi mengenai “Komponen-Komponen RPP”. Perubahan tersebut diakibatkan karena materi pada pertemuan pertama yang diharapkan selesai dalam 1 kali pertemuan menjadi mundur dan diselesaikan dalam 2 kali pertemuan. Salah satu penyebab adalah daya serap mahasiswa terhadap materi yang diberikan sedikit lambat. Hal tersebut juga tidak terlepas dari istilahistilah yang baru mesti dipahami oleh mahasiswa, seperti SK, KI dan KD.

Setelah diberikan penjelasan materi, selanjutnya mahasiswa diberikan tugas yang harus dipahami dan dikerjakan secara individu. Tugas yang diberikan tersebut juga dijadikan sebagai data yang berhubungan langsung dengan aktifitas kegiatan belajar mahasiswa, seperti kedisiplinan dalam mengumpulkan tugas sesuai waktu yang dikumpulkan serta kesesuaian tugas yang dikerjakan sesuai dengan apa yang diperintahkan. Hal ini merupakan bagian dari indikator kemampuan SRL mahasiswa yaitu kesadaran akan tujuan belajar dan kontinuitas belajar. Berikut data yang telah dihimpun selama 3 kali pertemuan di siklus II.

Setelah selesai proses pembelajaran pada siklus II, peneliti juga memberikan penghargaan kepada mahasiswa. Pada siklus II ini akan diberikan penghargaan kepada mahasiswa yang menujnukan perubahan aktifitas belajar yang semakin baik. Hal tersebut dilihat dari keaktifan di kelas, kedisiplinan datang tepat waktu, ketepatan dia mengumpulkan tugas dan kesesuaian dalam mengerjakan tugas yang diperintahkan.

Berdasarkan lembar observasi yang diisi oleh tim peneliti, aktifitas dosen dalam menerapkan hypnoteaching secara keseluruhan sudah berjalan dengan baik. Hal tersebut diakibatkan karena dosen cukup mengenal hamper semua mahasiswa karena pada semester sebelumnya sudah diajarkan dalam mata kuliah strategi pembelajaran matematika. Sehingga dosen bisa lebih mudah menerapkan hypnoeaching $\neg$ tanpa merasa kaku dan langsung bisa diterima oleh mahasiswa. 
Hasil Analisis Skor Angket SelfReguleted Learning dan Angket Hypnoteaching pada Siklus II

Setelah dilakukan perkuliahan selama 3 kali pertemuan, di akhir pertemuan ketiga peneliti meminta mahasiswa untuk mengisi angket self-regulated learning dan angket hypnoteaching. Berdasarkan perhitungan skor angket self-regulated learning diperoleh data pada tabel 9.

Dari Tabel 9, perhitungan skor angket pada siklus I kemampuan SRL mahasiswa mengalami peningkatan yaitu dari $72 \%$ menjadi 74\%. Untuk lebih jelas, peneliti juga mendeskripsikan skor angket SRL perindikator seperti pada tabel 10 .

Jika dilihat perindikator, sebaran skor yang diperoleh dari siklus II menunjukan sikap positif, jika dibandingkan dari pra siklus dan siklus I, persentase keempat indikator secara umum tersebut mengalami kenaikan walau ada satu indikator yang sama yaitu kesadaran akan tanggung jawab belajar. Untuk lebih jelasnya sebaran data indikator pada siklus I dan siklus II dapat dilihat pada Gambar 3.

Grafik di atas menunjukan adanya kenaikan skor dari pra siklus, siklus I dan Siklus II. Jika dilihat dari kriteria penskoran maka pada siklus II semua indikator sudah berada dikategori tinggi.

Perbandingan Hasil Analisis Skor Angket Kemampuan Self-Regulated Learning pada Pra Siklus, Siklus I, dan Siklus II

Dari Tabel 11 di atas, terlihat dengan jelas perubahan peningkatan kemampuan self-regulated learning mahasiswa, dari pra siklus, ke siklus I dan siklus II. Walaupun ada satu indikator yang memiliki persentase skor yang tetap sama dari siklus I ke siklus II. Akan tetapi secara umum, kemampuan self-regulated learning mahasiswa meningkat.

Terdapatnya peningkatan terhadap kemampuan self-regulated learning mahasiswa disebabkan oleh penarapan hypnoteaching dalam pembelajaran. Adanya hypnosis dalam hypnoteaching bukan berarti peneliti membuat mahasiswa tidak sadarkan diri seperti orang yang sedang dihipnotis, namun yang dilakukan adalah mengkondisikan keadaan untuk menciptakan kondisi kondusif dalam proses pembelajaran. Terciptanya kondisi pembelajaran yang seperti itu diharapkan menjadi salah satu factor yang mempengaruhi self-regulated learning mahasiswa. Saat peneliti menerapkan hypnoteaching dalam proses pembelajaran, mahasiswa dalam keadaan sadar seutuhnya dengan mata terbuka, mahasiswa hanya dibuat rileks pikirannya sehingga bisa focus dengan apa yang disampaikan oleh peneliti. Salah satu tahapan hypnoteaching adalah pacing yaitu pemberian sugesti-sugerti ataupun kata-kata positif. Hal ini bertujuan untuk mengkondisikan mahasiswa suapaya merasa nyaman dan dapat menikmati setiap proses pembelajaran yang dilakukan. Pemberian sugesti dan katakata positif di awal pembelajaran, menjadi salah satu factor untuk meningkatkan kemampuan self-regulated learning mereka. Salah satunya untuk mengarahkan mereka keprilaku positif dan aktifitas belajar yang bertanggung jawab. Seperti yang diungkapkan oleh Edistria (2012) bahwa hypoteaching merupakan penyampaian proses pembelajaran dengan cara memberikan sugesti menggunakan kata-kata persuasif untuk mengondisikan peserta didik agar berada dalam kondisi fokus. Sejalan dengan itu Yustisia (2012) juga mengungkapkan bahwa pemberian sugesti dilakukan untuk "mengaktifkan" pikiran bawah sadar mereka, karena pikiran bawah sadar (sub-conscisius mind) memiliki pengaruh lebih besar terhadap perilaku, pola pikir, sikap, dan kebiasaan dari pada pikiran sadar (conscisius mind) tiap individu. Sugesti yang diberikan juga bisa menjadi suatu alat yang kuat dan sangat membantu seseorang membuat perubahan positif dalam hidup mereka (Banyan, 2005). Kondisi seperti itu diharapkan mampu membatu dosen untuk dapat mengarahkan pikiran, perasaan, dan 
tingkah laku mahasiswa ke arah positif seperti mengatur kegiatan belajar, mengontrol prilaku belajar, serta mengetahui kebutuhan belajarnya sendiri. Selain memberikan kata-kata atau sugesti positif, di awal pembelajaran guru juga melakukan gerakan sederhana atau kelaksasi untuk mengatur pernafasan agar mengkondisikan mereka agar siap untuk menjalani proses pembelajaran tanpa memikirkan hal-hal lain yang dapat menggangu konsentrasi mereka saat proses pembelajaran dilakukan. Seperti yang diungkapkan oleh Noer (2010) yaitu salah satu cara untuk mengkondisikan siswa agar siap untuk belajar adalah dengan meminta siswa duduk di kursi dengan rileks dan santai., setelah itu semua siswa diajak untuk menghela nafas, menariknya dalam-dalam lewat hidung dan menahannya di dada sebentar untuk kemudian melepaskannya lewat mulut secara perlahan. Selain itu Ismuzaroh (2013) juga mengatakan bahwa relaksasi penting untuk dilakukan oleh pengajar sendiri dan juga kepada siswa. Kondisi rileks akan membuat peserta didik berkonsentrasi penuh pada arahan pengajar, dan pengajar akan fokus untuk memberikan arahan dan contoh yang terbaik buat peserta didik selama pembelajaran.

Pacing dan relaksasi yang dilakukan diawal perkuliahan memudahkan dosen untuk memperbaiki perilaku belajarnya. Upaya untuk melakukan perubahan perilaku belajar menjadi lebih baik, dapat berupa kesadaran akan tanggungjawab belajar dan kesadaran akan tujuan belajar. Hal tersebut diharapkan berdampak kepada peningkatakan kemampuan selfregulated learning mereka. Seperti yang diungkapkan oleh Paris \& Newman (1990) yaitu self-regulated learning juga menekankan pentingnya peserta didik mengetahui tujuan dari kegiatan belajarnya, peserta didik yang sudah tahu pasti tujuan dari kegiatan belajarnya akan mengarahkan segala pemikiran, perasaan, penerapan starategi, dan tingkah lakunya untuk mencapai tujuan yang telah ditetapkan dan mempertahankan prestasi akademiknya.

Selain pacing ada satu lagi tahapan hypnoteaching yang juga berperan dalam mengembangkan kemampuan selfregulated learning mahasiswa yaitu leading. Peneliti melakukan leading saat berkeliling untuk mengontrol kegiatan mahasiswa dalam mengertjakan tugas yang diberikan. Melalui leading peneliti memberikan sugesti positif kepada mahasiswa bahwa mereka bisa melakukan yang terbaik dalam pembelajaran. Leading yang dilakukan diharapkan dapat membuat mahasiswa menjadi bersemangat, termotivasi serta yakin dengan kemampuan mereka sendiri. Munculnya motivasi dan keyakinan dari dalam diri bisa mempengaruhi perkembangan kemampuan self-regulated learning mereka. Seperti yang diungkapkan oleh Stone, Schunk \& Swartz (Cobb, 2003) self-regulated learning, dipengaruhi oleh tiga faktor utama, yaitu keyakinan diri, motivasi dan tujuan.

Agar tahapan leading memberikan pengaruh yang maksimal kepada mahasiswa, peneliti menujukan sikap simpati dan empati serta memposisikan mahasiswa sebagai teman diskusi untuk sharing terkait materi yang dipelajari agar mahasiswa merasa nyaman dan tidak merasa tertekan dengan tugas-tugas yang diberikan. Diharapkan dengan leading yang dilakukan memudahkan peneliti untuk mengarahkan mahasiswa agar membuka pikiran mereka untuk berusaha mengerjakan tugas yang diberikan dengan baik. Pengarahan diri untuk dapat melakukan yang terbaik merupakan salah satu hal yang dapat mengembangkan selfregulated learning yang juga berpengaruh terhadap peningkatan kemampuan akademik mereka. Seperti yang diungkapkan oleh Zimmerman (2002) bahwa SRL lebih merupakan proses pengarahan diri dalam 
mentransformasikan kemampuan mental mereka ke dalam keterampilan akademis.

Tahapan lain dalam hypnoteaching adalah memberikan penghargaan kepada mahasiswa yang berusaha melakukan yang terbaik dalam perkuliahan. Pemberian Reward memang tidak berpengaruh langsung kepada kemampuan self-regulated learning akan tetapi bisa membuat mahasiswa menjadi termotivasi untuk melakukan yang terbaik yang mereka bisa lakukan. Reward yang peneliti berikan berupa barang-barang untuk keperluan mereka dalam perkuliahan, seperti buku, dan alat tulis. Alasan peneliti memilih barang sebagai bentuk hadiah adalah latar belakang mereka yang sebagain besar berasal dari keluarga yang tidak mampu. Reward yang diberikan diharapkan dapat bermanfaat dan digunakan langsung untuk keperluan kuliah mereka.

Berdasarkan analisis skor angket terkait kemampuan self-regulated learning yang dilakukan terlihat bahwa terjadi peningkatan skor sikap yaitu yang awalnya $61 \%$ pada pra siklus, naik menjadi $72 \%$ pada siklus I dan naik lagi menjadi $74 \%$ pada siklus II. Jika dilihat secara detail berdasarkan indikator kemampuan self-regulated learning maka hampir secara keseluruhan semua indikator juga mengalami peningkatan seperti yang terlihat pada Tabel 5.15. Walaupun ada satu indikator yang memiliki persentase skor yang tetap sama dari siklus I ke siklus II. Yaitu indikator "kesadaran akan tanggung jawab belajar" yang tidak mengalami peningkatan pada dari silkus I ke siklus II yaitu masih sama sebesar 73\%.. Walaupun secara keseluruhan besar persentasenya masih dibawah $80 \%$, Akan tetapi secara umum, kemampuan self-regulated learning mahasiswa mengalami peningkatan dan dapat dikatakan bahwa peningkatan tersebut disebabkan oleh penerapan hypnoteaching yang dilakukan. Terkait respon mahasiswa terhadap penerapan hypnoteaching, hasil analisis skor angket menunjukan skor sikap lebih besar dari skor netral yaitu 84\% pada siklus I dan 86 $\%$ pada siklus II dengan skor netral sebesar 55\%. Hal tersebut dapat diartikan bahwa mahasiswa memberikan respon positif terhadap penerapan hypnoteaching yang dilakukan. Sedangkan jika dilihat dari kriteria persentase skornya maka respon mahasiswa terhadap penerapan hypnoteaching berada pada kategori sangat baik sekali.

\section{KESIMPULAN DAN SARAN}

Berdasarkan hasil pengolahan data dan pembahasan, maka dapat disimpulkan bahwa analisis skor diperoleh kesimpulan bahwa kemampuan Self-Regulated Learning mahasiswa Papua di Mata Kuliah Desain Pembeajaran Matematika mengalami peningkatan.

Berdasarkan penelitian yang dilakukan maka terdapat beberapa saran yang bisa dilakukan oleh pihak-pihak yang tertarik melakukan penelitian yang sejenis. Penerapan hypnoteaching ini sangat erat dengan penggunaan kata "hypnosis" yang dalam masyarakat pada umumnya masih dianggab sesuatu yang berdampak buruk. Maka perlu peran dari pengajar untuk menjelaskan baik kepada siswa maupun semasa rekan pengajar bahwa hypnoteaching ini adalah sesuatu yang bagus dan baik untuk diterapkan.

\section{UCAPAN TERIMA KASIH}

Penulis mengucapkan terima kasih kepada Kemenristekdikti melalui Ditjen Penguatan Riset dan Pengembangan, atas dukungan dana penulisan, melalui Hibah Penulisan Dosen Pemula Tahun 2017.

\section{DAFTAR PUSTAKA}

Banyan, D. Calvin. (2005). Book self hypnosis-get on the path and program yourself for success. Stdy Guide for the 7th Path TM SelfHypnosis. 
Cobb, R.J., (2003). The relationship between self-regulated learning behaviors and academic performance in web-based course. Disertation, Virginia: Blacksburg.

Edistria, Ega (2012). Pengaruh Penerapan Hypnoteaching dalam ProblemBased Learning terhadap Kemampuan Komunikasi dan Berfikir Kreatif Matematis Siswa Sekolah Menengah Pertama. Tesis. Universitas Pendidikan Indonesia. Tidak diterbitkan

Hendriana, H., \& Soemarmo U. 2014. Penilaian Pembelajaran Matematika. Bandung: PT. Refika Aditama.

Ismuzaroh, S. (2013). Penerapan Hypnoteaching melalui Neuro Linguistic Programming dalam Pembelajaran Kimia. Jurnal Pendidikan IPA Indonesia (JPPI) 2 (2) (2013) 178-182.

Kesumawati, Nila. (2010). Pemahaman Matematis, Pemecahan Masalah dan Skala Disposisi. Universitas Pendidikan Indonesia.

Noer, M. (2010). Hypnoteaching for Success Learning. Yogyakarta: PEDAGOGIA.

Paris, S.G. \& Newman, R.S. (1990). Developmental Aspects of Selfregulated learning. Journal Educational Psychologist. 25 (1), 87-102.

Yustisia, N. (2012). Hypnoteaching: seni ajar mengekslorasi otak peserta didik. Yogyakarta: Ar-Ruzz Media.

Zimmerman, B.J. (2002a). Becoming A Self-Regulated Learner: An overview. Theory Into Practice. Vol. 41. Number 2, Spring-Autumn, 64-70. 


\begin{tabular}{cccc}
\hline \multicolumn{4}{c}{ Menghadiri Perkuliahan Tepat Waktu } \\
\hline Keterangan & Pertemuan ke-1 & Pertemuan ke-2 & Pertemuan ke-3 \\
Banyak Mahasiswa & 10 & 11 & 14 \\
Persentase & $63 \%$ & $69 \%$ & $88 \%$ \\
\hline
\end{tabular}

Tabel 1. Data Aktifitas Kegiatan Mahasiswa yang Datang Tepat Waktu di Siklus I

\begin{tabular}{cccc}
\hline \multicolumn{4}{c}{ Membaca Materi Persiapan Perkuliahan } \\
\hline Keterangan & $\begin{array}{c}\text { Membaca materi } \\
\text { mengenai "MK } \\
\text { Desian } \\
\text { Pembelajaran" }\end{array}$ & $\begin{array}{c}\text { Membaca materi } \\
\text { tentang "Desain } \\
\text { Pembelajaran" }\end{array}$ & $\begin{array}{c}\text { Membaca materi tentang } \\
\text { "Perangkat Pembelajaran" }\end{array}$ \\
Banyak Mahasiswa & 0 & 7 & 10 \\
Persentase & $0 \%$ & $44 \%$ & $63 \%$ \\
\hline
\end{tabular}

Tabel 2 Data Aktifitas Kegiatan Belajar Mahasiswa \& Membaca Materi sebelum Perkuliahan di Siklus I

\begin{tabular}{|c|c|c|c|}
\hline \multicolumn{4}{|c|}{ Mengumpulkan Tugas Tepat Waktu } \\
\hline Keterangan & $\begin{array}{c}\text { Meringkas materi "Tugas, } \\
\text { Peran, dan Kompetensi } \\
\text { Guru" }\end{array}$ & $\begin{array}{c}\text { Meringkas materi } \\
\text { "Desain Pembelajaran" }\end{array}$ & $\begin{array}{c}\text { Meringkas materi } \\
\text { "Perangkat Pembelajaran" }\end{array}$ \\
\hline $\begin{array}{c}\text { Banyak } \\
\text { Mahasiswa }\end{array}$ & 5 & 9 & 13 \\
\hline Persentase & $31 \%$ & $56 \%$ & $81 \%$ \\
\hline \multicolumn{4}{|c|}{ Mengerjakan Tugas Sesuai yang diperintahkan } \\
\hline Keterangan & $\begin{array}{l}\text { Meringkas materi "Tugas, Peran, } \\
\text { dan Kompetensi Guru" }\end{array}$ & $\begin{array}{l}\text { Meringkas materi "Desain } \\
\text { Pembelajaran" }\end{array}$ & $\begin{array}{c}\text { Meringkas materi "Perangkat } \\
\text { Pembelajaran" }\end{array}$ \\
\hline $\begin{array}{c}\text { Banyak } \\
\text { Mahasiswa }\end{array}$ & 7 & 8 & 8 \\
\hline Persentase & $44 \%$ & $50 \%$ & $50 \%$ \\
\hline
\end{tabular}

Tabel 3 Aktifitas Kegiatan Belajar Mahasiswa Siklus I

\begin{tabular}{ccc}
\hline Skor Sikap & Skor Netral & Keterangan \\
\hline $\mathbf{7 2 \%}$ & $60, \%$ & Positif \\
\hline
\end{tabular}

Tabel 4. Deskripsi Skor Angket SRL Siklus I

\begin{tabular}{cccc}
\hline Indikator SRL & $\begin{array}{c}\text { Skor } \\
\text { Sikap }\end{array}$ & $\begin{array}{c}\text { Skor } \\
\text { Netral }\end{array}$ & Keterangan \\
\hline Kesadaran akan Tujuan Belajar & $76 \%$ & $60 \%$ & Positif \\
$\begin{array}{c}\text { Kesadaran akan Tanggung Jawab } \\
\text { Belajar }\end{array}$ & $73 \%$ & $60 \%$ & Positif \\
Kontinuitas Belajar & & & \\
Efisiensi Belajar & $68 \%$ & $60 \%$ & Positif \\
\hline
\end{tabular}

Tabel 5. Deskripsi Skor Perindikator Angket SRL Siklus I

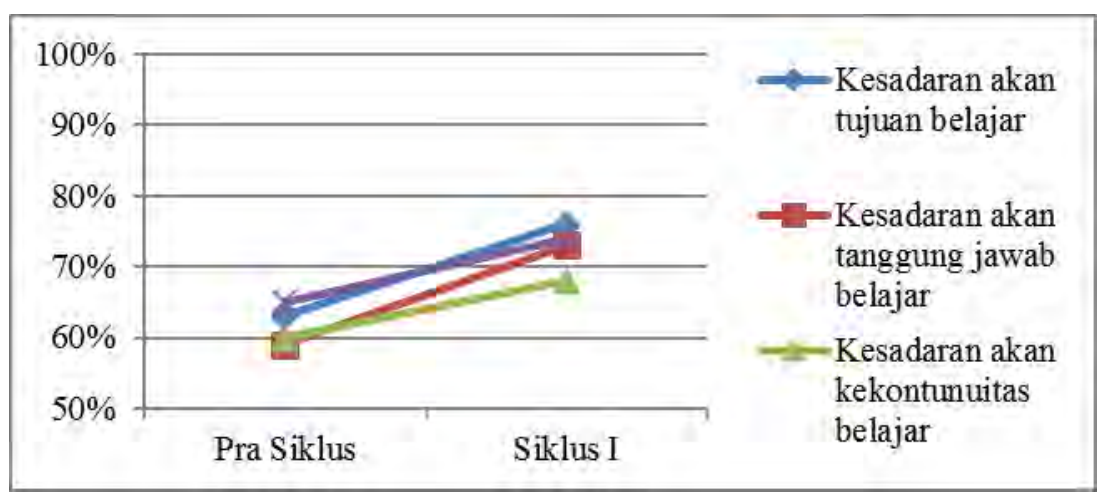


Gambar 2. Grafik Kenaikan Indikator Self-Regulated Learning Perindikator Siklus I

\begin{tabular}{cccc}
\hline \multicolumn{4}{c}{ Menghadiri Perkuliahan Tepat Waktu } \\
\hline Keterangan & Pertemuan ke-1 & Pertemuan ke-2 & Pertemuan ke-3 \\
Banyak Mahasiswa & 14 & 14 & 15 \\
Persentase & $88 \%$ & $88 \%$ & $94 \%$ \\
\hline Tabel 6 Data Aktifitas Kegiatan Mahasiswa & yang Datang Tepat Waktu pada Siklus II
\end{tabular}

Tabel 6 Data Aktifitas Kegiatan Mahasiswa yang Datang Tepat Waktu pada Siklus II

\begin{tabular}{cccc}
\hline & \multicolumn{2}{c}{ Membaca Materi Persiapan Perkuliahan } & \\
\hline Keterangan & $\begin{array}{c}\text { Membaca materi mengenai } \\
\text { "Hubungan Silabus dengan Prota, } \\
\text { Prosem, Kalender Pendidikan, dan } \\
\text { RPP" }\end{array}$ & $\begin{array}{c}\text { Membaca materi } \\
\text { tentang "Komponen- } \\
\text { Komponen Silabus" }\end{array}$ & $\begin{array}{c}\text { Membaca materi } \\
\text { tentang "Komponen } \\
\text { RPP" }\end{array}$ \\
$\begin{array}{c}\text { Banyak } \\
\text { Mahasiswa }\end{array}$ & 10 & 11 & 11 \\
Persentase & $63 \%$ & $69 \%$ & $69 \%$ \\
\hline
\end{tabular}

Tabel 7. Data Aktifitas Kegiatan Belajar Mahasiswa dalam Membaca Materi sebelum Perkuliahan di Siklus II

\begin{tabular}{|c|c|c|c|}
\hline \multicolumn{4}{|c|}{ Mengumpulkan Tugas Tepat Waktu } \\
\hline Keterangan & $\begin{array}{c}\text { Menuliskan tentang KI, SK } \\
\text { dan KD dan menuliskan } \\
\text { contohnya }\end{array}$ & $\begin{array}{c}\text { Membuat tujuan } \\
\text { pembelajaran } \\
\text { berdasarkan salah satu } \\
\text { KD }\end{array}$ & $\begin{array}{c}\text { Membuat RPP sesuai } \\
\text { dengan komponen } \\
\text { Peraturan Menteri selama } \\
2 \text { x } 40 \text { menit }\end{array}$ \\
\hline $\begin{array}{c}\text { Banyak } \\
\text { Mahasiswa }\end{array}$ & 14 & 14 & 15 \\
\hline Persentase & $88 \%$ & $94 \%$ & $94 \%$ \\
\hline \multicolumn{4}{|c|}{ Mengerjakan Tugas Sesuai yang diperintahkan } \\
\hline Keterangan & $\begin{array}{l}\text { Menuliskan tentang KI, SK } \\
\text { dan KD dan menuliskan } \\
\text { contohnya }\end{array}$ & $\begin{array}{c}\text { Membuat tujuan } \\
\text { pembelajaran } \\
\text { berdasarkan salah satu } \\
\text { KD }\end{array}$ & $\begin{array}{c}\text { Membuat RPP sesuai } \\
\text { dengan komponen } \\
\text { Peraturan Menteri selama } \\
2 \text { x } 40 \text { menit }\end{array}$ \\
\hline $\begin{array}{c}\text { Banyak } \\
\text { Mahasiswa }\end{array}$ & 8 & 8 & 9 \\
\hline Persentase & $50 \%$ & $50 \%$ & $56 \%$ \\
\hline
\end{tabular}

Tabel 8. Aktifitas Kegiatan Belajar Mahasiswa Siklus I pada Siklus II

\begin{tabular}{cccc}
\cline { 2 - 3 } & Skor Sikap & Skor Netral & \multicolumn{2}{c}{ Keterangan } \\
\cline { 2 - 3 } & \multicolumn{2}{c}{$60 \%$} & \multirow{2}{*}{ Positif } \\
\cline { 2 - 3 } & Tabel 9. Deskripsi Skor Angket SRL Siklus II & \\
\hline Indikator SRL & Skor & Skor & \multirow{2}{*}{ Keterangan } \\
& Sikap & Netral & \\
\hline Kesadaran akan Tujuan Belajar & $76 \%$ & $60 \%$ & Positif \\
Kesadaran akan Tanggung Jawab & $73 \%$ & $60 \%$ & Positif \\
Belajar & & & \\
Kontinuitas Belajar & $71 \%$ & $60 \%$ & Positif \\
Efisiensi Belajar & $76 \%$ & $60 \%$ & Positif \\
\hline
\end{tabular}

Tabel 10. Deskripsi Skor Perindikator Angket SRL Siklus II 


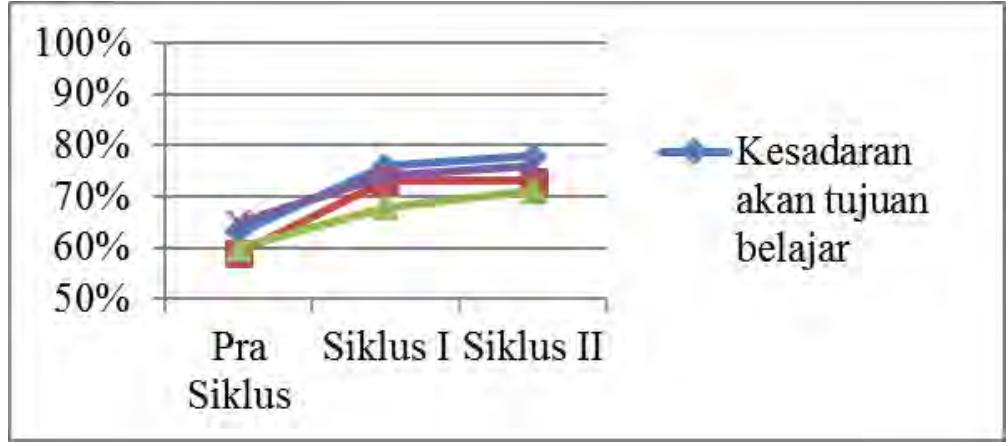

Gambar 3 Grafik Kenaikan Indikator Self-Regulated Learning Perindikator

\begin{tabular}{ccccc}
\hline Aspek & $\begin{array}{c}\text { Pra } \\
\text { Siklus }\end{array}$ & Siklus I & Siklus II & Keterangan \\
\hline $\begin{array}{c}\text { Kemampuan Self-Regulated Learning secara } \\
\text { umum }\end{array}$ & $61 \%$ & $72 \%$ & $74 \%$ & Meningkat \\
$\begin{array}{c}\text { Kemampuan Self-Regulated Learning pada } \\
\text { indikator "kesadaran akan tujuan belajar" }\end{array}$ & $63 \%$ & $76 \%$ & $78 \%$ & Meningkat \\
$\begin{array}{c}\text { Kemampuan Self-Regulated Learning pada } \\
\text { indikator "kesadaran akan tanggung jawab } \\
\text { belajar" }\end{array}$ & $59 \%$ & $73 \%$ & $73 \%$ & Meningkat \\
$\begin{array}{c}\text { Kemampuan Self-Regulated Learning pada } \\
\text { indikator "kontinuitas belajar" }\end{array}$ & $60 \%$ & $68 \%$ & $71 \%$ & Meningkat \\
\hline $\begin{array}{c}\text { Kemampuan Self-Regulated Learning pada } \\
\text { indikator "efisiensi belajar" }\end{array}$ & $65 \%$ & $74 \%$ & $76 \%$ & Meningkat \\
\hline
\end{tabular}

Tabel11. Perbandingan Analisi Skor Angket 
